\title{
Detection and Classification of SPLCV Isolates in the U.S. Sweetpotato Germplasm Collection via a Real-Time PCR Assay and Phylogenetic Analysis
}

\author{
N. A. Barkley, D. L. Pinnow, and M. L. Wang, United States Department of Agriculture-Agricultural Research Service (USDA-ARS), \\ Plant Genetic Resources Conservation Unit, Griffin, GA 30223; K. S. Ling, USDA-ARS, U.S. Vegetable Laboratory, Charleston, SC \\ 29414 USA; and R. L. Jarret, USDA-ARS, Plant Genetic Resources Conservation Unit, Griffin, GA
}

\begin{abstract}
Barkley, N. A., Pinnow, D. L., Wang, M. L., Ling, K. S., and Jarret, R. L. 2011. Detection and classification of SPLCV isolates in the U.S. sweetpotato germplasm collection via a real-time PCR assay and phylogenetic analysis. Plant Dis. 95:1385-1391.

The United States Department of Agriculture-Agricultural Research Service sweetpotato (Ipomoea batatas) germplasm collection contains accessions that were initially collected from various countries worldwide. These materials have been maintained and distributed as in vitro plantlets since the mid-1980s. The status of viral infection by the emerging Sweet potato leaf curl virus (SPLCV) and other Begomovirus spp. in this germplasm has yet to be determined. In order to minimize the potential distribution of virus-infected clones, all accessions in the collection were tested for SPLCV using a real-time polymerase chain reaction assay. In total, 47 of 701 accessions of in vitro plantlets tested positive for SPLCV. The presence of SPLCV detected in these materials was confirmed via biological indexing using the indicator plants $I$. nil and I. muricata. Symptoms appeared more rapidly on I. muricata than on I. nil. Nucleotide polymorphisms among the isolates were

evaluated by sequencing the AV1 coat protein gene from 24 SPLCVinfected accessions. The results revealed that the SPLCV isolates shared high sequence identity. Ten nucleotide substitutions were identified, most of which were synonymous changes. Phylogenetic analysis was conducted on those 24 SPLCV isolates in combination with six described SPLCV species and various SPLCV strains from GenBank to evaluate the relationships among viral species or strains. The results from this analysis indicated that most of the AV1 genes derived from previously classified SPLCV species clustered together, some of which formed well-supported monophyletic clades, further supporting the current taxonomy. Overall, identification of SPLCV-infected germplasm will allow approaches to be employed to eliminate the virus from the collection and limit the distribution of infected materials.
\end{abstract}

The cultivated sweetpotato (Ipomoea batatas (L.) Lam.), which has a basic chromosome number of $x=15$ and ploidy levels of $4 x$ and $6 x(23)$, are classified in the family Convolvulaceae (tribe Ipomoeae). Believed to have originated in Central and South America (29), they currently are cultivated in most tropical, subtropical, and temperate regions of the world (19), with $80 \%$ of the global production occurring in China (16). The United States produced an average of 768,382 metric tons of sweetpotato on 37,418 ha in 2008 (North Carolina Sweetpotato Commission, www.ncsweetpo tatoes.com/component/content/article/182.html). Sweetpotato plants are adaptable and can yield well in adverse environmental conditions because of their tolerance to high temperatures, low-fertility soils, and a relatively short growing season (11). Sweetpotato is highly versatile as a food source because both the fleshy storage roots and the vines (stems and leaves) can be consumed as food or fodder by man and animals (36). Sweetpotato is often a staple food that plays a major role in controlling vitamin A deficiency (33). Because of the importance of sweetpotato as a staple food, cultivar decline in which yield or quality traits deteriorate has become a valid concern (4) in many areas that are heavily dependent on this crop.

The cultivated sweetpotato is propagated vegetatively through vine cuttings or "slips". Although this is an efficient means of

Corresponding author: N. A. Barkley, E-mail: Elle.Barkley@ars.usda.gov

Mention of trade names or commercial products in this article is solely for the purpose of providing specific information and does not imply recommendation or endorsement by the United States Department of Agriculture.

Accepted for publication 1 June 2011.

doi:10.1094/PDIS-01-11-0012

This article is in the public domain and not copyrightable. It may be freely reprinted with customary crediting of the source. The American Phytopathological Society, 2011. propagation, it provides a vehicle for the perpetuation and distribution of systemic (and to some extent localized) viruses or pathogens which can be spread among seasons and growing areas from the propagating source material $(4,12)$. Numerous viruses that infect sweetpotato have been identified and characterized. These include Sweet potato feathery mottle virus, Sweet potato virus $G$, Ipomoea vein mosaic virus, Ipomoea yellow vein virus (IYVV), Sweet potato chlorotic stunt virus, Sweet potato leaf curl virus (SPLCV), and others. More than 15 viruses are currently known to infect the crop, many of which are transmitted by either aphids or whiteflies (20). Historically, there were two main obstacles to the identification of sweetpotato viruses. The first of these was the difficulty of isolating and purifying the virus. The second was the high incidence of mixed infections and synergistic interactions that induced diseases (12). Until recently, only minimal efforts were made to control specific viral pathogens because the virus either had not been fully characterized or its effect on the crop had not been substantially evaluated (4). Regardless, viral infection of the crop can be a major constraint to food production and can result in yield reductions of up to $90 \%$ (19).

SPLCV is a DNA virus classified in the genus Begomovirus (family Geminiviridae). Begomovirus spp. cause many economically important diseases, resulting in significant yield losses to crop plants throughout the world $(6,27)$. There are currently over 100 species of Begomovirus that are vectored by whiteflies (Bemisia tabaci and $B$. argentifolii), which spread diseases to a range of dicotyledonous host plants $(6,20)$. Plant viruses classified as Geminiviridae are characterized by genomes that are circular single-stranded DNA packaged as twin-isometric particles $(6,20)$. These viruses typically have bipartite genomes (DNA-A and DNAB). However, many of the Old World Begomovirus spp. generally have only a monopartite genome (6). DNA-A is the largest component that encodes genes involved in DNA replication, control of gene expression, and insect transmission, while DNA-B encodes genes (nuclear shuttle protein and cell-to-cell movement protein [MP]) required for inter- and intracellular movement of the repli- 
cated virus within the host $(3,9,20)$. SPLCV has a genome consistent with Old World Begomovirus spp.; therefore, they are monopartite, with no DNA-B component, and are phylogenetically distinct from other Begomovirus spp. $(3,20)$. Although Begomovirus spp. are known to cause significant losses to crops, little is currently known about the variability among sweetpotato Begomovirus isolates (19).

SPLCV was first reported in Taiwan and Japan (22) but has since been detected in Ipomoea spp. around the world, including China (20), Italy (2), Kenya (21), Peru (7), Spain (19), Brazil (24), and the United States $(16,18)$. However, the prevalence and distribution of the virus in these areas are still largely unknown (32). Recent research has shed light on the distribution of the virus and its host range. Lotrakul et al. reported that only 14 of 152 Ipomoea plants collected in the United States were infected with SPLCV, suggesting that the virus might not be common (17). However, SPLCV was demonstrated to be commonly found in breeding lines and in the purple-leafed ornamentals (4). Ling et al. determined that 41 Ipomoea spp. were capable of serving as hosts for SPLCV, suggesting that infected plants of wild species potentially could serve as inoculum for the infection of sweetpotato cultivated nearby (15).

SPLCV infection of sweetpotato can frequently go undetected because symptoms are often easily missed. This species does not readily display evident foliar symptoms upon infection $(4,14,32)$. Generally, Ipomoea plants infected with multiple viruses exhibit more visible symptoms and reduction in yields than plants infected with a single virus (16). Infection with monopartite viral genomes which lack the DNA-B component are often asymptomatic because they do not express the MP, which has been shown to be a major symptom determinant $(3,9)$. However, the C4 protein (DNA-A genome) in Begomovirus spp. has also been suggested as a pathogenicity determinant $(13,37)$. Nevertheless, leaf curl symptoms in sweetpotato are not common and may not persist (32) throughout the plant's life cycle. The occurrence of the leaf curl characteristic in response to infection is genotype and environment dependent and may require the presence of other viruses for expression (5). In some Ipomoea spp., such as I. aquatica, I. fistulosa, and I. cordatotriloba, SPLCV infection can yield yellow vein symptoms (17). Field evaluations have demonstrated that SPLCV infection can significantly reduce the yield of sweetpotato lines (16). Further, quality traits such as periderm color and longitudinal grooves in the storage roots were affected by infection with SPLCV (4). Given that SPLCV has been detected in most major sweetpotato production areas, and that whitefly populations and their host ranges continue to increase, SPLCV is anticipated to have a significant impact on the sweetpotato industry $(16,28)$ going forward.

The United States Department of Agriculture-Agricultural Research Service (USDA-ARS) Plant Genetic Resources Conservation Unit (PGRCU) maintains an in vitro collection of sweetpotato samples for the purpose of germplasm preservation and utilization (10). The original nucleus of the collection was acquired from a breeding program which maintained the clones as storage roots. Later additions were introduced as in vitro virus-indexed tissue cultures. Currently, all clones are maintained as in vitro cultures in order to prevent viral infection by limiting exposure to various vectors, and to eliminate the space and labor required to grow and harvest the storage roots in the field or to perpetually maintain plants in a greenhouse. This germplasm collection has never been entirely assessed for the presence of all viruses known to infect sweetpotato. Maintaining these accessions in tissue culture precludes the ability to visually evaluate them for viral infection because significant morphological characteristics or diagnostic symptoms of most common diseases are not always evident on the in vitro plantlets. Many accessions were acquired prior to the initial discovery of SPLCV. Consequently, in an attempt to identify infected clones and prevent dissemination of this virus, the entire USDA-ARS sweetpotato germplasm collection was tested for the presence of SPLCV using a real-time polymerase chain reaction (PCR)-based assay. Real-time PCR has been shown to be an effi- cient method for the detection of Begomovirus spp. in sweetpotato when compared with conventional PCR (12). Therefore, the objectives of this study were to (i) determine the extent of SPLCV infection within the USDA-ARS sweetpotato germplasm collection using a real-time PCR assay, (ii) confirm the results via biological indexing on an appropriate indicator plant species which displays clear morphological symptoms, and (iii) sequence virus isolates and determine their variability and relationship to other SPLCV species or isolates.

\section{Materials and Methods}

Plant material and DNA extraction. Plant material was acquired from the USDA-ARS PGRCU sweetpotato germplasm collection in Griffin, GA. Positive controls W-370 and W-285 (18) were obtained from the USDA-ARS Vegetable Laboratory (Charleston, SC) and were maintained in a growth chamber $(12 \mathrm{~h}$ of light at $28^{\circ} \mathrm{C}$ and $12 \mathrm{~h}$ of darkness at $24^{\circ} \mathrm{C}$ ) to prevent the virus from spreading to other germplasm. Plant tissue for analysis was harvested from either in vitro plantlets or accessions maintained in a greenhouse. (As far as the authors are aware, no studies have been performed on the distribution of SPLCV in a plant upon infection or how the environment plays a role in titer levels). Approximately $100 \mathrm{mg}$ of plant leaf tissue was collected and placed in a 2-ml screw-cap microcentrifuge tube containing two 3-mm tungsten carbide beads (Qiagen, Valencia, CA). Tissue was pulverized with a Retsch Mixer Mill 201 (Leeds, UK) for 3 min at 30 hertz and the DNA was subsequently extracted using the E.Z.N.A. Plant DNA kit (Omega Bio-Tek, Norcross, GA). DNA concentrations were determined on a DyNA Quant 200 fluorometer (Hoefer Pharmacia Biotech, San Francisco). DNA concentrations and extract quality were also determined by comparison with a quantitative marker (Low Mass Ladder; Invitrogen, Carlsbad, CA) on 1\% agarose gels stained with ethidium bromide. Samples were subsequently diluted to $10 \mathrm{ng} / \mu \mathrm{l}$ for PCR. Following the dilution, $1 \mu \mathrm{l}$ of each sample was again run on a $1 \%$ agarose gel with the Low Mass Ladder (Invitrogen) and stained with ethidium bromide in order to ensure the accuracy of the dilutions.

Real-time PCR. The primers and probe used in the reactions targeted the coat protein gene (AV1) in the SPLCV genome. The sequences of the forward and reverse primers were $5^{\prime}$ GAG ACA GCT ATC GTG CC 3' and 5' GAA ACC GGG ACA TAG CTT CG 3', respectively. Primers were synthesized by Eurofins MWG Operon (Huntsville, AL). The TaqMan probe was synthesized by Applied Biosystems (Foster City, CA) and consisted of a $5^{\prime}$ reporter fluorophore, $3^{\prime}$ minor groove binder (MGB), and 3' nonfluorescent quencher (NFQ). The sequence of the probe was $5^{\prime}$ 6FAM TAC ACT GGG AAT GCT GTC CCA ATT GCT MGBNFQ 3'. The development of primers and probes was as described previously to detect all sweetpotato Begomovirus spp. based on nucleotide sequence alignment (16). The PCR product size was $67 \mathrm{bp}$. Optimum primer and probe concentrations were determined empirically by testing a matrix of various primer-probe combinations. The concentrations chosen were those that maximized the normalized reporter fluorescence and minimized the cycle threshold $\left(\mathrm{C}_{\mathrm{T}}\right)$. Reaction volumes were $20 \mu \mathrm{l}$ and consisted of: $1 \times$ TaqMan Gene Expression Master Mix (Applied Biosystems), $0.15 \mu \mathrm{M}$ forward and reverse primer, $0.15 \mu \mathrm{M}$ 6-FAM probe, and template DNA at $0.5 \mathrm{ng} / \mu \mathrm{l}$. The TaqMan Gene Expression Master Mix included AmpliTaq Gold polymerase, Uracil-DNA Glycosylase to minimize carryover PCR contamination, and ROX, which is a passive internal reference to correct for signal variation between wells. Cycling conditions were 1 cycle of $60^{\circ} \mathrm{C}$ for $30 \mathrm{~s}, 1$ cycle of $50^{\circ} \mathrm{C}$ for 2 min, 1 cycle of $95^{\circ} \mathrm{C}$ for $10 \mathrm{~min}, 35$ cycles of $95^{\circ} \mathrm{C}$ for $15 \mathrm{~s}$ and $60^{\circ} \mathrm{C}$ for $1 \mathrm{~min}$, and a final cycle of $60^{\circ} \mathrm{C}$ for $30 \mathrm{~s}$. All cycling was performed with an ABI StepOne Real-Time PCR system in MicroAmp fast optical 48-well plates (Applied Biosystems). Two replicate reactions of no template controls were included in each run to ensure that all reagents were free of contaminants. Each run also included a positive control (SPLCV-infected W-285 or W-370) and a negative control (healthy PI 566655). Each sample was analyzed 
as described previously and also was duplicated with a spike of the positive control to ensure that no PCR inhibition was occurring. PCR efficiency was evaluated by constructing a standard curve from the DNA of the positive control (W-370) with a five-point serial sample dilution (replicated in triplicate). These results demonstrated a $98.69 \%$ efficiency rate with an $r^{2}=1$ and $m=$ -3.354. The difference in the $C_{T}$ values among the replicates of each dilution ranged from 0.01 to 0.20 , indicating precision at each dilution point.

Sequencing isolates and data analysis. A set of primers specific for the detection of SPLCV coat protein sequence (AV1) was used to amplify and produce a PCR product. The sequences of the forward and reverse primers were 5' AAGAAATACGAGCCAG GAAC $3^{\prime}$ and 5' TATTAATTATTGTGCGAATCA 3', respectively. The total product size was $839 \mathrm{bp}$. The primers were synthesized by Eurofins MWG Operon. The PCR reactions consisted of $\mathrm{H}_{2} \mathrm{O}$, $1 \times$ PCR buffer, $3.125 \mu \mathrm{M} \mathrm{MgCl}_{2}, 0.2 \mathrm{mM}$ dNTPs (Promega Corp., Madison, WI), Taq DNA polymerase at $0.1 \mathrm{U} / \mu \mathrm{l}$ (Promega Corp.), $0.1 \mu \mathrm{M}$ forward and reverse primers, and template DNA at 0.75 $\mathrm{ng} / \mu \mathrm{l}$. The cycling conditions were 1 cycle of $95^{\circ} \mathrm{C}$ for $5 \mathrm{~min}$; followed by 38 cycles of $95^{\circ} \mathrm{C}$ for $1 \mathrm{~min}, 55^{\circ} \mathrm{C}$ for $30 \mathrm{~s}$, and $72^{\circ} \mathrm{C}$ for $1 \mathrm{~min} ; 1$ cycle of $72^{\circ} \mathrm{C}$ for $10 \mathrm{~min}$; and a $4^{\circ} \mathrm{C}$ hold. All PCR reactions were performed on a 96-well GeneAmp PCR System 9700 (Applied Biosystems). PCR products were purified by treating with exonuclease I at $1 \mathrm{U} / \mu \mathrm{l}$ and Shrimp Alkaline Phosphatase at $0.1 \mathrm{U} / \mu \mathrm{l}$ (GE Healthcare, Piscataway, NJ) and incubating at $37^{\circ} \mathrm{C}$ for $15 \mathrm{~min}$ followed by $80^{\circ} \mathrm{C}$ for $15 \mathrm{~min}$ to activate and inactivate the enzymes, respectively. Products were further purified via the QIAquick PCR purification kit (Qiagen) to remove excess nucleotides, primers, enzymes, and other impurities. The purified products were sent to the core facility at the University of Georgia (Athens) for bidirectional sequencing on a 3730xl 96-capillary DNA Analyzer (Applied Biosystems).

Sequences were initially edited and aligned using AlignIR (v 2.0; Li-Cor, Lincoln, NE). Additional sequences of the AV1 gene from the SPLCV genome and IYVV (which is similar to SPLCV; 20) were obtained from GenBank. There are six recognized SPLCV species: Sweet potato leaf curl Canary virus (SPLCCaV), Sweet potato leaf curl China virus (SPLCCV), Sweet potato leaf curl Georgia virus (SPLCGV), Sweet potato leaf curl Lanzarote virus (SPLCLaV), Sweet potato leaf curl Spain virus (SPLCESV), and SPLCV according to the International Committee on Taxonomy of Viruses (http://www.ictvonline.org/index.asp). Sequences of AV1 from the SPLCV species in GenBank were added to the isolates sequenced from the U.S. collection for analysis. ClustalX (31) was used to determine the optimal alignment and the percent nucleotide identity. High and low gap penalties were employed; however, changing the gap penalties did not produce significant changes in the alignment. jModelTest v 0.1.1 (25) was used to statistically select a model of nucleotide substitution by comparing and calculating the log likelihood (-LnL) from a total of 88 possible models to find the optimum model for the data set. Selecting an appropriate model using statistical selection is significant because the chosen model can strongly affect branch lengths and overall tree topology (1). The Akaike information criterion (AIC), Bayesian information criterion (BIC), and decision theory criteria were used to test for the selection of the appropriate substitution model. The AIC criterion chose TIM2+I+G with a $-\mathrm{LnL}=-3126.1335$, whereas the BIC criterion chose $\mathrm{TPM} 3+\mathrm{I}+\mathrm{G}$ with a $-\mathrm{LnL}=$ -3136.2776 . The likelihood ratio test (LRT) was calculated to test the likelihood of the two best models with the data. The value of the LRT was 18.0738 , with a $P$ value $=0.002856$, suggesting that the TIM2+I+G was the most appropriate substitution model. Phylogenetic trees were estimated using probabilistic methods. Tree searching was conducted using a heuristic search random stepwise addition along with tree bisection and reconnection branch swapping. PAUP* $\beta$ version $4.0 \mathrm{~b} 10$ (30) was employed to construct a phylogeny via maximum likelihood. Bootstrapping was performed to test clade stability with 100 replicates. Bootstrap values of $70 \%$ or higher are indicated on the branches. Seventy percent or higher was chosen because this value has been demonstrated to correspond to a well-supported clade (8).

Biological indexing. In vitro clones testing positive for SPLCV were transferred to soil and grown in a quarantine greenhouse to produce vine cuttings for grafting to indicator plants. The terminal three-quarter-inch-long section of each infected I. batatas accession was cut from the plant and all leaves and petioles were removed, except for those tiny emerging leaves on the terminal bud. This scion was cleft grafted to the host plant branch stem. The graft was then wrapped in a double layer of Parafilm and covered with a clear plastic bag sufficiently large so as to not touch the top of the graft yet long enough to be closed loosely with tape around the indicator plant stem below the graft. Bags were removed 9 to 14 days later, when the grafts were successfully established and the scions were actively growing. Ungrafted indicator plants were included as controls. SPLCV-positive accessions were graft inoculated onto two indicator plants, PI 279698 (I. muricata) and Griffin (Grif) 15200 'Scarlett O'Hara' (I. nil). These graft-inoculated plants were maintained in a greenhouse under quarantine conditions. Bioassays were performed in May and the symptoms were monitored over a period of 11 weeks. All grafted plants used were also tested for SPLCV utilizing the real-time PCR assay previously described.

\section{Results}

Identification of SPLCV positives. In total, 701 in vitro plantlets were tested for the presence of SPLCV using a real-time PCR assay (Fig. 1). Of these, 47 accessions (6.7\%) tested positive for SPLCV. The $\mathrm{C}_{\mathrm{T}}$ of the accessions determined to be positive ranged from 14.78 to 29.95 , with a mean and standard deviation of 21.81 and 4.03 , respectively. Only one accession testing positive ('Florida'/PI 16175) was originally collected and introduced into the collection from the United States. The other 46 originated from either collections or donations from countries around the world (Table 1). Several of these 47 SPLCV-positive accessions were introduced into the United States through the plant germplasm quarantine system (Table 1). The majority of these accessions were received prior to 1998; therefore, they may not have been specifically tested for SPLCV because this virus was unknown in the United States prior to 1998 (18).

A small number of sweetpotato clones and several clonally propagated Ipomoea spp. which are distributed as vine cuttings (including I. carnea, I. littoralis, and I. microdactyla) are routinely

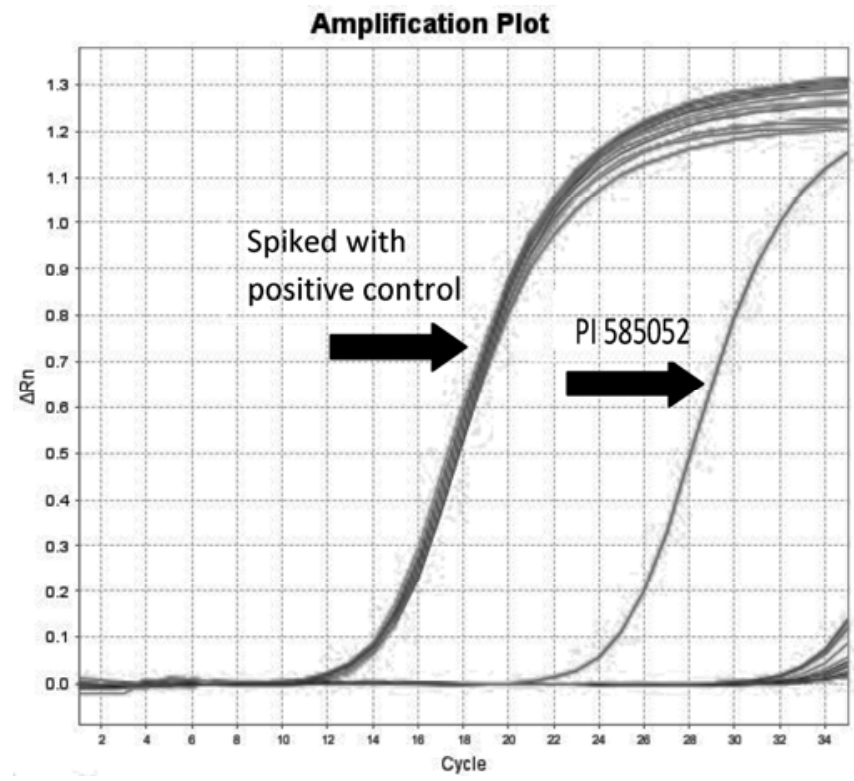

Fig. 1. Amplification plot from the Sweet potato leaf curl virus real-time polymerase chain reaction (PCR) assay. Samples that first cross the cycle threshold are all spiked with a positive control to test all reactions for PCR inhibition. The next sample crossing the cycle threshold is PI 585052. 
maintained in a greenhouse in lieu of maintaining them as in vitro plantlets. In an attempt to evaluate the prevalence of this virus in a greenhouse environment, leaf tissue was collected and the realtime PCR assay was employed to evaluate the presence or absence of the virus in these materials. Accessions of I. batatas, I. littoralis, and I. microdactyla that were maintained in the greenhouse were determined to be infected with SPLCV, whereas I. carnea (PI 566635) was determined to be negative for SPLCV (data not shown). In total, 85 plants from the greenhouse were tested. Of these, $26(30.58 \%)$ were determined to be positive for SPLCV. The $\mathrm{C}_{\mathrm{T}}$ values ranged from 12.47 to 29.9 with a mean value of 19.97 and a standard deviation of 5.19, respectively. Overall, the rate of infection in the greenhouse was much higher than the rate of infection of material maintained in vitro.

Verification of SPLCV via bioassay. A bioassay was performed to confirm the real-time PCR results. All samples from the bioassay were maintained in a greenhouse that contained only grass species which are not known to be hosts for SPLCV. No whiteflies were observed in the greenhouse during the time that the bioassay was performed. Two indicator species (I. nil and I. muricata) were used to determine which species was the most effective in displaying symptoms of the virus and, further, which species produced symptoms in a timely manner. I. nil and I. muricata both displayed leaf curling after being grafted with scions from SPLCV-positive accessions. Leaves of I. nil also became chlorotic. Symptom development was observed on I. nil indicator plants 10.5 weeks after grafting and on I. muricata after 3.5 weeks (data not shown). Leaf curling on I. nil was more difficult to detect compared with I. muricata when the scions originated from plants with low titer levels and, thus, had late $\mathrm{C}_{\mathrm{T}}$ values $\left(\mathrm{C}_{\mathrm{T}}>25\right)$. Difference in symptom development, however, could be due to differential reactions of the genotypes selected for the bioassay or could be due to the specific environmental conditions utilized over the period of time when the biological index was performed. Real-time PCR analysis of leaves from the grafted plants revealed $\mathrm{C}_{\mathrm{T}}$ results comparable with the initial test of in vitro plantlets, confirming the indicator plant results.

Table 1. List of Ipomoea batatas accessions in the in vitro germplasm collection determined to be positive for Sweet potato leaf curl virus ${ }^{\mathrm{a}}$

\begin{tabular}{|c|c|c|c|c|c|c|c|c|c|}
\hline PI & Genus & Species & Variety & Accession name & Location $^{b}$ & Quar. & $\begin{array}{l}\text { NPGS } \\
\text { received }\end{array}$ & $\begin{array}{l}\text { PGRCU } \\
\text { received }\end{array}$ & $\mathrm{C}_{\mathrm{T}}^{\mathrm{c}}$ \\
\hline 16175 & Ipomoea & batatas & batatas & Florida & Virginia (C) & No & 1905 & 2007 & 15.58 \\
\hline 208886 & Ipomoea & batatas & batatas & 527 & Puerto Rico (C) & No & 1953 & 1987 & 17.11 \\
\hline 318856 & Iротоеа & batatas & batatas & N.Z. 643 & Peru (C) & No & 1966 & 1987 & 24.16 \\
\hline 344122 & Iротоеа & batatas & batatas & N.Z. 25 & Hong Kong (C) & No & 1969 & 1987 & 28.40 \\
\hline 399163 & Iротоеа & batatas & batatas & Camote morado & Guatemala (D) & No & 1972 & 1988 & 24.34 \\
\hline 439749 & Ipomoea & batatas & batatas & $\ldots$ & $\operatorname{Mexico}(\mathrm{C})$ & No & 1980 & 1980 & 23.41 \\
\hline 508513 & Iротоеа & batatas & batatas & Simon-1 & Brazil (D) & No & 1986 & 1987 & 23.18 \\
\hline 508524 & Ipomoea & batatas & batatas & Mina & Puerto Rico (D) & No & 1986 & 1988 & 22.80 \\
\hline 508526 & Iротоеа & batatas & batatas & Miguela-21 & Puerto Rico (D) & No & 1986 & 1988 & 16.72 \\
\hline 508529 & Iротоеа & batatas & batatas & Miguela-24 & Puerto Rico (D) & No & 1986 & 1987 & 21.71 \\
\hline 531093 & Ipomoea & batatas & batatas & Camote morado & Guatemala (C) & No & 1984 & 1989 & 20.51 \\
\hline 531095 & Ipomoea & batatas & batatas & Camote morado & Guatemala (C) & No & 1984 & 1989 & 17.27 \\
\hline 531097 & Ipomoea & batatas & batatas & Camote morado & Guatemala (C) & No & 1984 & 1989 & 23.25 \\
\hline 538295 & Ipomoea & batatas & batatas & Yuca de Calango & Peru $(\mathrm{C})$ & No & 1989 & 1987 & 27.70 \\
\hline 564109 & Ipomoea & batatas & batatas & C 16679 & Peru (D) & Yes & 1985 & 1992 & 18.44 \\
\hline 564119 & Iротоеа & batatas & batatas & CN 1232-9 & Taiwan (D) & Yes & 1989 & 1992 & 23.16 \\
\hline 564120 & Iротоеа & batatas & batatas & CN 1510-25 & Taiwan (D) & Yes & 1989 & 1992 & 16.50 \\
\hline 566616 & Iротоеа & batatas & batatas & Carolina Nugget & North Carolina (D) & No & 1993 & 2007 & 16.14 \\
\hline 566633 & Ipomoea & batatas & batatas & Hidry & South Carolina (D) & No & 1993 & $\ldots$ & 14.78 \\
\hline 566641 & Ipomoea & batatas & batatas & Nancy Hall & Florida (D) & No & 1993 & $\ldots$ & 28.60 \\
\hline 573293 & Ipomoea & batatas & batatas & Hawhua & Philippines (C) & Yes & 1991 & 1993 & 22.88 \\
\hline 573320 & Ipomoea & batatas & batatas & $83002-103$ & Tonga $(\mathrm{C})$ & Yes & 1991 & 1993 & 28.47 \\
\hline 573324 & Ipomoeа & batatas & batatas & IB08 & Samoa (C) & Yes & 1991 & 1993 & 20.23 \\
\hline 585052 & Ipomoea & batatas & batatas & $83003-13$ & Tonga $(\mathrm{C})$ & Yes & 1991 & 1994 & 25.27 \\
\hline 592992 & Ipomoea & batatas & batatas & 95 & Peru (D) & Yes & 1985 & 1995 & 16.42 \\
\hline 592996 & Ipomoea & batatas & batatas & IPS 141 & Australia (D) & Yes & 1993 & 1995 & 21.37 \\
\hline 595887 & Ipomoea & batatas & batatas & Tanzania & Peru (D) & Yes & 1995 & 1996 & 22.96 \\
\hline 599394 & Iротоеа & batatas & batatas & Beerwah Gold & Peru (D) & Yes & 1996 & 1997 & 29.95 \\
\hline 599397 & Iротоеа & batatas & batatas & TIS 8401 & Peru (D) & Yes & 1996 & 1997 & 19.28 \\
\hline 612683 & Iротоеа & batatas & batatas & WT-399 & Peru (D) & Yes & 1998 & 1999 & 22.08 \\
\hline 612684 & Ipomoea & batatas & batatas & WT-532 & Peru (D) & Yes & 1998 & 1999 & 24.48 \\
\hline 612685 & Ipomoea & batatas & batatas & LM 87.045 & Peru (D) & Yes & 1998 & 1999 & 18.63 \\
\hline 614798 & Ipomoea & batatas & batatas & WT-237 & Peru (D) & Yes & 1998 & 2000 & 20.77 \\
\hline 634405 & Ipomoea & batatas & batatas & TG-3 & South Carolina (D) & No & 1987 & 1987 & 24.46 \\
\hline 634406 & Iротоеа & batatas & batatas & TG-4 & South Carolina (D) & No & 1987 & 1989 & 23.17 \\
\hline 634409 & Iротоеа & batatas & batatas & TG-7 & South Carolina (D) & No & 1987 & 1989 & 20.07 \\
\hline 634417 & Ipomoea & batatas & batatas & W-9 & South Carolina (D) & No & 1987 & 1989 & 18.47 \\
\hline 634444 & Ipomoea & batatas & batatas & $\mathrm{W}-230$ & South Carolina (D) & No & 1987 & 1987 & 19.40 \\
\hline 634446 & Iротоеа & batatas & batatas & $\mathrm{W}-232$ & South Carolina (D) & No & 1987 & 1987 & 18.42 \\
\hline 634453 & Iротоеа & batatas & batatas & $\mathrm{W}-245$ & South Carolina (D) & No & 1987 & 1987 & 21.30 \\
\hline 634460 & Ipomoea & batatas & batatas & White Triumph & South Carolina (D) & No & 1987 & 1987 & 27.90 \\
\hline 634462 & Ipomoea & batatas & batatas & $81-52$ & South Carolina (D) & No & 1987 & 1987 & 18.24 \\
\hline 634466 & Ipomoea & batatas & batatas & MD 16-8 & North Carolina (D) & No & 1991 & 1991 & 18.97 \\
\hline 634469 & Ipomoea & batatas & batatas & MD 17-340 & North Carolina (D) & No & 1991 & 1991 & 18.80 \\
\hline 641933 & Ipomoea & batatas & batatas & Agena & Hawaii (D) & No & 2004 & 2005 & 23.70 \\
\hline 641934 & Iротоеа & batatas & batatas & Molokai Purple & Hawaii (D) & No & 2004 & 2005 & 26.21 \\
\hline 645582 & Ipomoea & batatas & batatas & Okinawa Purple & Japan (C) & No & 2007 & 2007 & 29.60 \\
\hline
\end{tabular}

${ }^{a}$ The year in which the germplasm was acquired by the National Plant Germplasm System (NPGS) and acquired by the United States Department of Agriculture-Agricultural Research Service (USDA-ARS) Plant Genetic Resources Conservation Unit (PGRCU) is listed in the table. Accessions that went through quarantine (Quar.) before they were added to the USDA-ARS germplasm collection are listed in the table.

${ }^{\mathrm{b}}$ Collected (C) or donated (D).

${ }^{\mathrm{c}}$ Cycle threshold. 
Sequence and classification of SPLCV isolates. Twenty-four SPLCV-positive samples (GenBank accession number HQ207503 to HQ270526) from the greenhouse and the in vitro clones were amplified with primers targeting the AV1 (coat protein) gene and sequenced to evaluate variability among the isolates. An unrooted consensus tree using a maximum likelihood approach was constructed to show the relationships among the 24 USDA isolates for AV1 (Fig. 2A). Bootstrap values $>60 \%$ were placed on the branches. These 24 isolates separated into two distinct clusters. In total, 10 variable sites were observed in the alignment of 24 sequences obtained from the 24 SPLCV-positive samples. Four of the 10 single-nucleotide polymorphisms detected were found in all individuals grouped into a single cluster. The majority (9 of 10) of these polymorphic sites were synonymous with changes that occurred in the third position of the codon based on a comparison of translated
AV1 coding sequence deposited in GenBank. One of the detected polymorphisms, however, was a missense change of a nonpolar phenylalanine to a polar tyrosine occurring in the second position of the codon. BLAST results demonstrated that these sequences were most similar to SPLCV isolates from Korea (FJ560719), with 96\% identity, a bit score of 1,269 , and $\mathrm{E}$ values of 0.0 .

The relationships among the SPLCV isolates detected in the U.S. germplasm collection and SPLCV isolates or species deposited in GenBank were evaluated by constructing a phylogenetic tree using $718 \mathrm{bp}$ of sequence from the AV1 gene (Fig. 2B). The percent nucleic acid identity was also calculated between the USDA germplasm collection isolates, SPLCV species, and IYVV (Table 2). This resulted in an overall identity rate ranging from 86 to $100 \%$ in AV1 among the isolates or species. A probabilistic approach using maximum likelihood was used with the TIM $2+\mathrm{I}+\mathrm{G}$
A

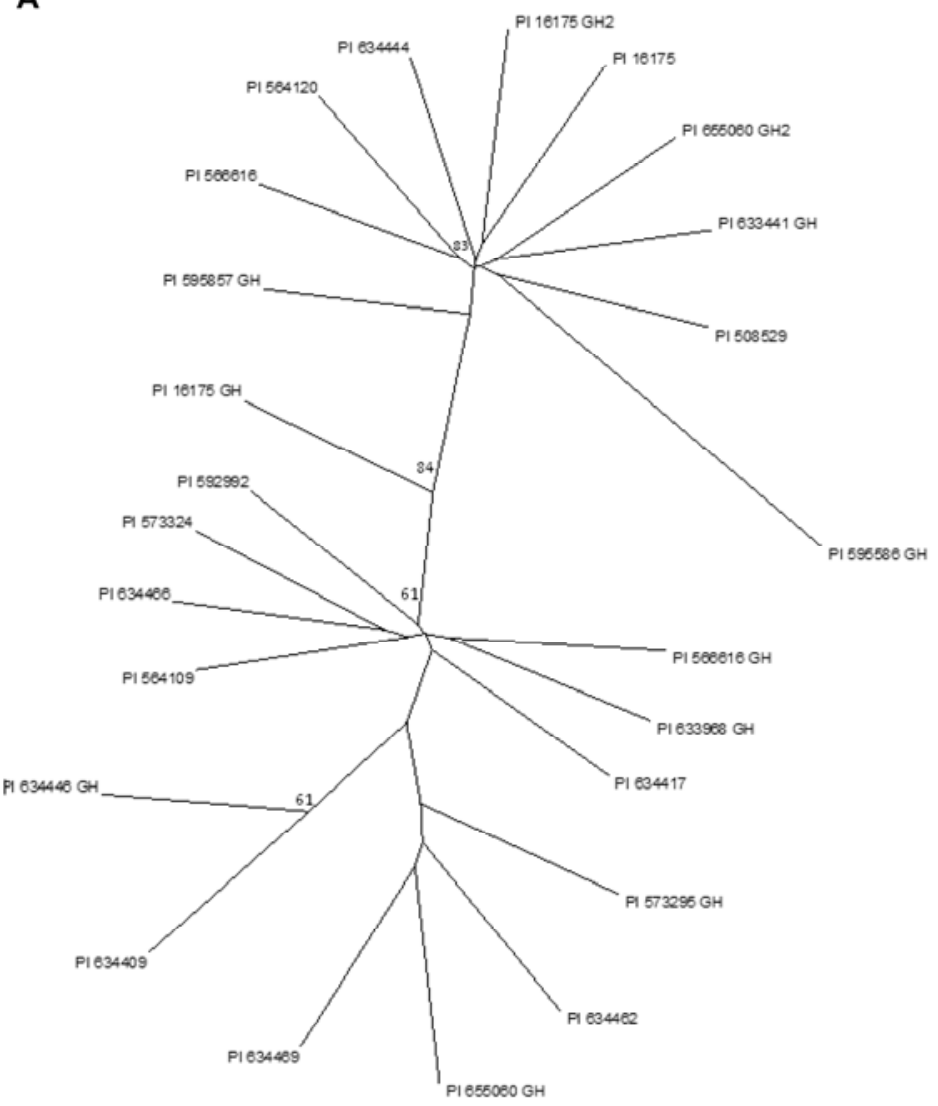

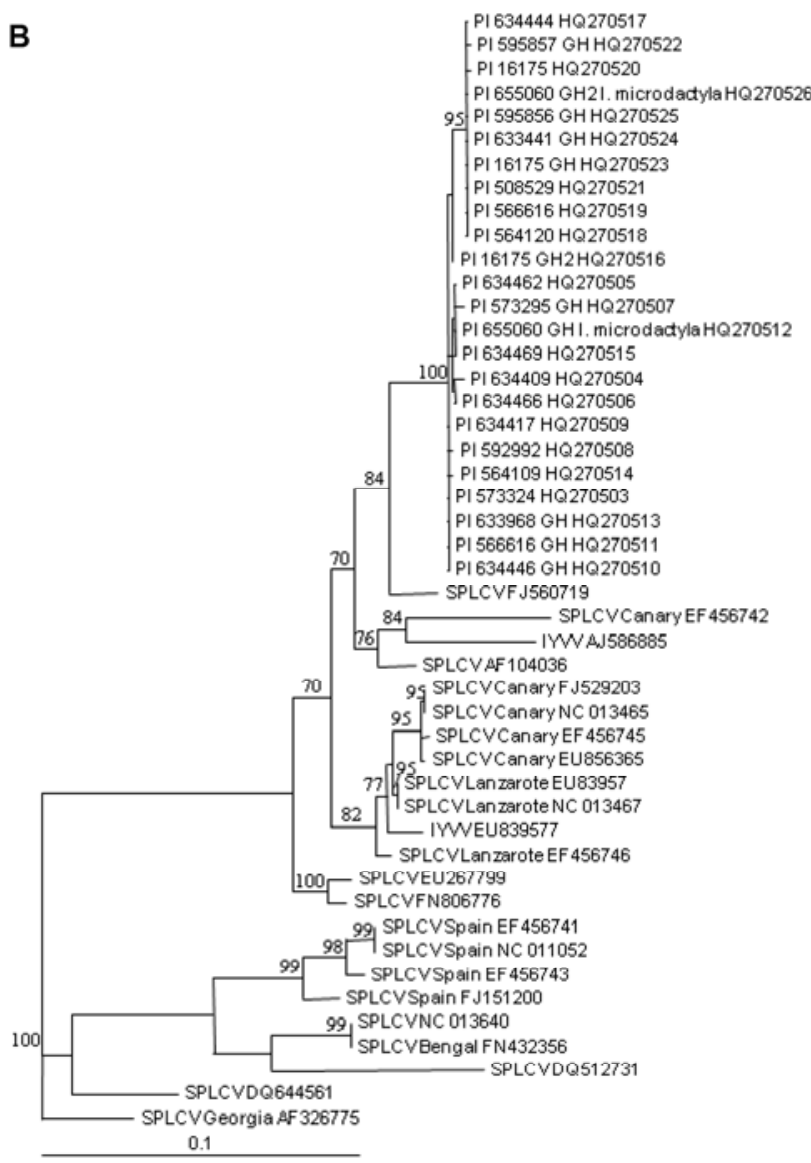

Fig. 2. A, Consensus tree showing the relationships among isolates from the United States Department of Agriculture (USDA) germplasm collection. The USDA Agricultural Research Service (ARS) Sweet potato leaf curl virus (SPLCV) isolates are labeled with a PI number to indicate the in vitro plantlet infected with SPLCV and, if the sample came from the greenhouse, it is also labeled with $\mathrm{GH}$ for greenhouse. Bootstrap values greater than $60 \%$ are placed on the branches. B, Phylogenetic tree showing the relationships between SPLCV species and isolates. The USDA-ARS SPLCV isolates are labeled with a PI number to indicate the in vitro plantlet infected with SPLCV and, if the sample came from the greenhouse, it is also labeled with $\mathrm{GH}$ for greenhouse. Bootstrap values greater than $70 \%$ are placed on the branches. The recognized SPLCV species-SPLCV, Sweet potato leaf curl Spain virus (SPLCESV), Sweet potato leaf curl Canary virus (SPLCCaV), Sweet potato leaf curl Lanzarote virus (SPLCLaV), and Sweet potato leaf curl Georgia virus (SPLCGV) - were included along with other SPLCV isolates all downloaded from GenBank. GenBank accession numbers are labeled on the leaves following the SPLCV species.

Table 2. Summary of the range of percent nucleotide identity calculated between U.S. sweetpotato germplasm isolates, Sweet potato leaf curl Canary virus (SPLCCaV), Sweet potato leaf curl China virus (SPLCCV), Sweet potato leaf curl Georgia virus (SPLCGV), Sweet potato leaf curl Lanzarote virus (SPLCLaV), Sweet potato leaf curl Spain virus (SPLCESV), and Ipomoea yellow vein virus (IYVV)

\begin{tabular}{|c|c|c|c|c|c|c|c|}
\hline Isolates & $\begin{array}{c}\text { U.S. } \\
\text { germplasm }\end{array}$ & $\begin{array}{c}\text { SPLCCV } \\
\text { China }\end{array}$ & $\begin{array}{c}\text { SPLCCaV } \\
\text { Canary }\end{array}$ & $\begin{array}{l}\text { SPLCESV } \\
\text { Spain }\end{array}$ & $\begin{array}{l}\text { SPLCLaV } \\
\text { Lanzarote }\end{array}$ & $\begin{array}{c}\text { SPLCGV } \\
\text { Georgia }\end{array}$ & IYVV \\
\hline US Germplasm & $99-100$ & $\ldots$ & $\ldots$ & $\ldots$ & $\ldots$ & $\ldots$ & $\ldots$ \\
\hline SPLCCV China & $94-95$ & 99 & $\ldots$ & $\ldots$ & $\ldots$ & $\ldots$ & $\ldots$ \\
\hline SPLCCaV Canary & $93-96$ & $93-96$ & $93-100$ & . & $\ldots$ & $\ldots$ & $\ldots$ \\
\hline SPLCESV Spain & $85-86$ & $86-87$ & $85-87$ & $97-100$ & $\ldots$ & $\ldots$ & $\ldots$ \\
\hline SPLCLaV Lanzarote & $95-96$ & 96 & $94-99$ & $86-88$ & 98-99 & $\ldots$ & $\ldots$ \\
\hline SPLCGV Georgia & $89-90$ & 91 & 90 & 90 & $90-91$ & 100 & $\ldots$ \\
\hline IYVV & $93-95$ & $93-95$ & $93-98$ & $86-88$ & $95-99$ & 90 & 94 \\
\hline
\end{tabular}


substitution model applied in the tree construction. SPLCGV was the most divergent from the other USDA germplasm collection sequences in this data set (Table 2); therefore, it was chosen as the outgroup. All of the SPLCV isolates obtained from the USDA germplasm collection clustered together and were supported by a bootstrap value of $100 \%$. They were closely related to the SPLCV isolate from Korea (FJ560719), the same isolate with high similarity via the BLASTn search results. Little AV1 sequence divergence was observed among the isolates from the USDA germplasm collection. Thus, the branch lengths among the isolates were very short. It is possible that all USDA germplasm collection accessions are all infected with a single SPLCV species or strain. However, further sequencing of the genome would be required in order to assess this possibility, because species are delineated by $<89 \%$ nucleotide identity of DNA-A. Monophyly was observed for all of the SPLCESV AV1 sequences. This clade was well supported, with a bootstrap value of $99 \%$. All of the SPLCLaV and SPLCCaV species generally clustered together but did not form distinct monophyletic clades. The branch lengths between SPLCLaV and SPLCCaV sequences were also short, suggesting that these two species are closely related.

\section{Discussion}

Sweetpotato is an important food and industrial crop that provide sustenance to people worldwide. However, the common practice of vegetative propagation for sweetpotato allows disease-infected plant material to be readily disseminated (12). This includes numerous viruses known to infect sweetpotato. Sweetpotato Begomovirus spp. have been detected in several countries worldwide, especially in areas where sweetpotato is grown. Due to the lack of visually detectable symptoms upon infection with SPLCV, the occurrence of this virus may have been seriously underestimated (16). However, the inability of many lines to develop symptoms may also suggest some tolerance or resistance to SPLCV infection via unintentional selection (16). Lotrakul et al. (18) found that SPLCV-US did not induce symptoms on 'Beauregard', 'Tanzania', or breeding line TIB-8, but did produce leaf curling on breeding line W-285. Additional studies are needed to determine which cultivars can tolerate or resist SPLCV infection and whether symptom development occurs due to synergistic infection of multiple viruses, the genotype infected, the environment, or expression of genes encoded from the DNA-A genome.

The detection of Begomovirus spp. via amplification of the AV1 gene can sometimes be problematic because the coat protein may fail to be amplified from extracts of plants exhibiting symptoms or may be amplified from asymptomatic plants (19). This phenomenon of amplifying the AV1 gene from asymptomatic plants was observed in evaluating the USDA-ARS sweetpotato germplasm collection. Therefore, reliance on visual symptoms to identify infection has not proven to be a consistent, effective detection method. Failure of PCR to amplify the coat protein can result from PCR inhibition, a low titer level (12), or poor PCR efficiency. Any of these could possibly influence the number of false negatives in a data set. Some of the problems associated with accurate detection can be overcome by employing appropriate positive controls, negative controls, testing for PCR inhibition in each run, including an internal marker gene to assess PCR effectiveness, and evaluating PCR efficiency with a standard curve. Because sweetpotato plants are known to have phenolic compounds, latex, and inhibitors (26), all samples in this study were tested for PCR inhibition by running duplicate reactions that were spiked with a SPLCV-positive control. No incidences of inhibition were observed in this study. Further, a standard curve was established for this assay and it was determined that the assay was $98.69 \%$ efficient. However, it is possible that some SPLCV-positive accessions went undetected in this study due to low titer levels. Despite some of these potential limitations, real-time PCR in conjunction with indicator plant indexing has been demonstrated to be an effective method for the detection of SPLCV $(12,16)$ and was effective at detecting infection in the plant materials examined here.
The distribution of SPLCV in the United States and worldwide is still largely unknown (16). However, recent studies have demonstrated that this virus has been detected in Ipomoea spp. worldwide $(16,20,21)$ and, thus, may be fairly prevalent. Evaluation of the USDA sweetpotato in vitro germplasm collection revealed a fairly low infection rate $(6.7 \%)$, yet the infection rate of plants which reside only in the greenhouse was fairly high $(>30 \%)$. These results were not unexpected because greenhouse conditions often provide opportunities for the development and survival of insect vectors with population growth often exceeding normal conditions of population growth in a field (34). Sequencing the AV1 gene isolated from SPLCV-infected plants revealed few polymorphic sites, which suggests that the germplasm may be infected with a single SPLCV species. However, further sequencing of the genome from these viral isolates may reveal additional variation that would demarcate these isolates into multiple SPLCV species or discrete genotypes within a single species. Recently, Zhang and Ling (37) assigned 10 genotypes and a new proposed species (Sweet potato leaf curl South Carolina virus) by sequencing the entire genome of 52 field-collected isolates from Mississippi and South Carolina.

The USDA-ARS germplasm collection contains plant materials that originated from countries around the world. Infection of this germplasm likely occurred due to acquisition of infected material, germplasm regeneration, or cross contamination (horizontal transfer) during tissue culture regeneration. It is difficult to assess whether the germplasm was initially received infected because many of the accessions in this collection were acquired prior to the discovery of SPLCV and due to the lack of symptoms displayed upon infection. It is also feasible that some of the accessions became infected after acquisition, because the germplasm was originally regenerated in the field or a greenhouse prior to the mid1980s. Maintenance of the germplasm collection in vitro has largely precluded vector-based transmission within the collection, although the possibility of transmission during the reculture or regeneration process cannot be totally dismissed. Some materials have been maintained in culture for as long as 25 years and recultured more than 30 times. Regeneration of in vitro clones on a regular basis may eliminate infected material due to inadvertent selection of tissue that lacks the virus. On the other hand, it is also quite possible that vegetative regeneration of in vitro clones will perpetuate viral infection due to selection and propagation of diseased tissue. Although tools used during the reculture process are heat sterilized, the possibility of cross-contamination of cultures during this process cannot be totally dismissed.

This study examined the level of SPLCV infection in the U.S. sweetpotato germplasm collection, the majority of which is maintained in vitro. Maintenance and exchange of sweetpotato germplasm in vitro will help reduce the introduction and dissemination of new viral pathogens (16) because exposure to whiteflies and other vectors are limited. Nevertheless, in vitro germplasm collections which are distributed to worldwide requestors should be regularly evaluated for viruses to avoid distribution of infected clones. The results presented here demonstrate a low incidence $(6.7 \%)$ of SPLCV in the in vitro collection. Future work may include evaluating different methods such as meristem tip culture, thermotherapy, cryopreservation, or a mixture of multiple methods (35) to eliminate this virus from the germplasm collection and sequencing viral isolates to determine whether the germplasm is infected with a single or multiple SPLCV species. Given the increase in the vector that transmits the disease in the Southeast (16) and the high rate of infection detected in Ipomoea spp. maintained only in the greenhouse compared with the in vitro collection, in vitro maintenance of the germplasm collection is more likely to protect these genetic resources from diseases that are detrimental to sweetpotato.

\section{Acknowledgments}

We thank S. Moon for providing sweetpotato germplasm used in this study and Drs. G. Gillaspie and B. Guo for their comments to improve the manuscript. 


\section{Literature Cited}

1. Bos, D. H., and Posada, D. 2005. Using models of nucleotide evolution to build phylogenetic trees. Dev. Comp. Immunol. 29:211-227.

2. Briddon, R. W., Bull, S. E., and Bedford, I. D. 2006. Occurrence of Sweet potato leaf curl virus in Sicily. Plant Pathol. 55:286.

3. Briddon, R. W., Patil, B. L., Bagewadi, B., Nawaz-ul-Rehman, M. S., and Fauquet, C. M. 2010. Distinct evolutionary histories of the DNA-A and DNA-B components of bipartite begomoviruses. BMC Evol. Biol. 10:97.

4. Clark, C. A., and Hoy, M. W. 2006. Effects of common viruses on yield and quality of Beauregard sweetpotato in Louisiana. Plant Dis. 90:83-88.

5. Clark, C. A., Valverde, R. A., Fuentes, S., Salazar, L. F., and Moyer, J. W. 2002. Research for improved management of sweetpotato pests and diseases: cultivar decline. Acta Hortic. 583:103-112.

6. Fauquet, C. M., Bisaro, D. M., Briddon, R. W., Brown, J. K., Harrison, B. D., Rybicki, E. P., Stenger, D. C., and Stanley, J. 2003. Revision of taxonomic criteria for species demarcation in the family Geminiviridae, and an updated list of Begomovirus species. Arch. Virol. 148:405-421.

7. Fuentes, S., and Salazar, L. F. 2003. First report of Sweet potato leaf curl virus in Peru. Plant Dis. 87:98.

8. Hillis, D. M., and Bull, J. J. 1993. An empirical test of bootstrapping as a method for assessing confidence in phylogenetic analysis. Syst. Biol. 42:182-192.

9. Hussain, M., Mansoor, S., Iram, S., Fatima, A. N., and Zafar, Y. 2005. The nuclear shuttle protein of Tomato leaf curl New Delhi virus is a pathogenicity determinant. J. Virol. 79:4434-4439.

10. Jarret, R. L. 1989. A repository for sweet potato germplasm. Hortic. Sci. 25:885-886.

11. Karyeija, R. F., Gibson, R. W., and Valkonen, J. P. T. 1998. The significance of sweet potato feathery mottle virus in subsistence sweet potato production in Africa. Plant Dis. 82:4-15.

12. Kokkinos, C. D., and Clark, C. A. 2006. Real-time PCR assays for detection and quantification of sweetpotato viruses. Plant Dis. 90:783-788.

13. Krake, L. R., Rezaian, M. A., and Dry, I. B. 1998. Expression of the tomato leaf curl geminivirus $\mathrm{C} 4$ gene produces virus like symptoms. Mol. PlantMicrobe Interact. 11:413-417.

14. Li, R. H., Salih, S., and Hurtt, S. 2004. Detection of geminiviruses in sweetpotato by polymerase chain reaction. Plant Dis. 88:1347-1351.

15. Ling, K. S., Harrison, H., Simmons, A., and Jackson, D. 2008. Sweet potato leaf curl virus: virus reservoir in species of wild morning glory. In: (Abstr.) Natl. Sweetpotato Collaborators Group Progr. Rep. Meet. 8.

16. Ling, K. S., Jackson, D. M., Harrison, H., Simmons, A. M., and PesicVanEsbroeck, Z. 2010. Field evaluation of yield effects on the U.S.A. heirloom sweetpotato cultivars infected by Sweet potato leaf curl virus. Crop Prot. 29:757-765.

17. Lotrakul, P., Valverde, R. A., and Clark, C. A. 2002. Sweet potato leaf curl virus and related geminiviruses in sweetpotato. Acta Hortic. 583:135-141.

18. Lotrakul, P., Valverde, R. A., Clark, C. A., Sim, J., and De La Torre, R. 1998. Detection of a geminivirus infecting sweet potato in the United States. Plant Dis. 82:1253-1257.

19. Lozano, G., Trenado, H. P., Valverde, R. A., and Navas-Castillo, J. 2009. Novel Begomovirus species of recombinant nature in sweet potato (Ipomoea batatas) and Ipomoea indica: taxonomic and phylogenetic implications. J. Gen. Virol. 90:2550-2562.
20. Luan, Y. S., Zhang, J., Liu, D. M., and Li, W. L. 2007. Molecular characterization of Sweet potato leaf curl virus isolate from China (SPLCV-CN) and its phylogenetic relationship with other members of the Geminiviridae. Virus Genes 35:879-880.

21. Miano, D. W., LaBone, D. R., Clark, C. A., Valverde, R. A., Hoy, M. W., Hurtt, S., and Li, R. 2006. First report of a begomovirus infecting sweetpotato in Kenya. Plant Dis. 90:832.

22. Onuki, M., and Hanada, K. 1998. PCR amplification and partial nucleotide sequences of three dicot-infecting geminiviruses occurring in Japan. Ann. Phytopathol. Soc. Jpn. 64:116-120.

23. Ozias-Akins, P., and Jarret, R. L. 1994. Nuclear DNA content and ploidy levels in the genus Ipomoea. J. Am. Soc. Hortic. Sci. 119:110-115.

24. Paprotka, T., Boiteux, L. S., Fonseca, M. E., Resende, R. O., Jeske, H., Faria, J. C., and Ribeiro, S. G. 2010. Genomic diversity of sweet potato geminiviruses in a Brazilian germplasm bank. Virus Res 149:224-233.

25. Posada, D. 2008. jModelTest: phylogenetic model averaging. Mol. Biol. Evol. 25:1253-1256.

26. Reynoso Guterrez, D. L. 2008. Molecular diversity and coat protein expression of Sweet potato leaf curl virus. Dissertation, Louisiana State University.

27. Sharma, P., Rishi, N., and Malathi, V. G. 2005. Molecular cloning of coat protein gene of an Indian Cotton leaf curl virus (CLCuV-HS2) isolate and its phylogenetic relationship with others members of Geminiviridae. Virus Genes 30:85-91.

28. Simmons, A. M., Ling, K. S., Harrison, H. F., and Jackson, D. M. 2009. Sweet potato leaf curl virus: efficiency of acquisition, retention and transmission by Bemisia tabaci (Hemiptera: Aleyrodidae). Crop Prot. 28:1007-1011.

29. Srisuwan, S., Sihachakr, D., and Siljak-Yakovlev, S. 2006. The origin and evolution of sweet potato (Ipomoea batatas Lam.) and its wild relatives through the cytogenetic approaches. Plant Sci. 171:424-433.

30. Swofford, D. L. 1998. PAUP* Phylogenetic Analysis Using Parsimony (* and other methods), Version 4. Sinauer Associates, Sunderland, MA.

31. Thompson, J. D., Gibson, T. J., Plewniak, F., Jeanmougin, F., and Higgins, D. G. 1997. The CLUSTAL_X windows interface: flexible strategies for multiple sequence alignment aided by quality analysis tools. Nucleic Acids Res. 25:4876-4882.

32. Valverde, R. A., Clark, C. A., and Valkonen, J. P. T. 2007. Viruses and virus disease complexes of sweetpotato. Plant Viruses 1:116-126.

33. van Jaarsveld, P. J., Faber, M., Tanumihardjo, S. A., Nestel, P., Lombard, C. J., and Benade, A. J. 2005. Beta-carotene-rich orange-fleshed sweet potato improves the vitamin A status of primary school children assessed with the modified-relative-dose-response test. Am. J. Clin. Nutr. 81:1080-1087.

34. van Lenteren, J. C. 2000. A greenhouse without pesticides: fact or fantasy? Crop Prot. 19:375-384.

35. Wang, Q. C., and Valkonen, J. P. T. 2008. Elimination of two viruses which interact synergistically from sweetpotato by shoot tip culture and cryotherapy. J. Virol. Methods 154:135-145.

36. Woolfe, J. A. 1992. Sweet Potato: An Untapped Food Resource. Press Syndicate of the University of Cambridge, New York.

37. Zhang, S. C., and Ling, K. S. 2011. Genetic diversity of sweet potato begomoviruses in the United States and identification of a natural recombinan between Sweet potato leaf curl virus and sweet potato leaf curl Georgia virus. Arch. Virol. Online publication. doi:10.1007/s00705-011-0930-2. 